\title{
RELATION OF LITTER SIZE AND OTHER FACTORS TO THE DURATION OF GESTATION IN THE PIG
}

\author{
D. F. COX \\ Department of Animal Science, Iowa State University, Ames, Iowa, U.S.A. \\ (Received 9th Fanuary 1964)
}

\begin{abstract}
Summary. The negative correlation between the number of foetuses and the length of gestation characteristic of most multiparous species is not found in the pig. This observation, reported in previous studies, was confirmed using 1450 records from the Duroc and Hampshire breeds. The gestation period was also unrelated to either the number of late foetal deaths or to the weight and fatness of the sow but prolonged gestation at first parturition reduced the probability of a second litter.
\end{abstract}

Biggers, Curnow, Finn \& McLaren (1963) have pointed out that the duration of gestation varies inversely with the number of foetuses in mice, guinea-pigs, cattle, sheep, goats, rabbits and humans. None of the seven studies on gestation period in pigs, cited by these authors, showed any significant relationship between the number born and the length of gestation. The purpose of this brief report is to substantiate the existing evidence in the pig and to examine other sources of variation among 1450 gestation periods observed in 693 purebred Duroc and Hampshire sows.

The animals were assembled in 1959 to investigate the genetic effects of irradiation. Willham \& Cox (1962) have given details on the source of the original animals and the mating plan used in the herd. The length of gestation was recorded as the difference, in days, between the date of mating and the date of farrowing.

The distribution of the duration of gestation is given in Table 1. The 1450 pregnancies comprise 750 in Hampshire sows and 700 in Duroc sows. The average gestation period was 113.24 days in the former, and half a day longer in the latter, the difference being highly significant.

The variances and covariance of the litter size at birth and the length of gestation were obtained by pooling values calculated within groups of sows of like breed and age that were served by the same boar in the same season. The linear regression coefficient for the regression of the gestation period in days on the number of pigs born in the litter was $-0 \cdot 016 \pm 0 \cdot 020$. The correlation was $-0 \cdot 03$. Thus, in these data, as in previous studies, no significant relationship was found between litter size and duration of gestation.

Other factors were examined in a similar manner for their possible influence on the length of gestation. The incidence of late foetal death, measured by the 405 
number of regressing foetuses at birth, had no detectable influence on the duration of gestation. Live weight of the sow at 5 months, and her backfat thickness, also had no apparent relation to the duration of her first pregnancy.

\section{TABLE 1}

\begin{tabular}{|c|c|}
\hline \multicolumn{2}{|c|}{$\begin{array}{l}\text { DISTRIBUTION OF } 1450 \text { GESTA } \\
\text { TION PERIODS FROM } 700 \text { DURO } \\
\text { AND } 750 \text { HAMPSHIRE SOWS }\end{array}$} \\
\hline $\begin{array}{l}\text { Days of } \\
\text { gestation }\end{array}$ & $\begin{array}{c}\text { No. periods } \\
\text { observed }\end{array}$ \\
\hline $\begin{array}{r}<110 \\
110 \\
111 \\
112 \\
113 \\
114 \\
115 \\
116 \\
>116\end{array}$ & $\begin{array}{r}19 \\
38 \\
109 \\
211 \\
367 \\
329 \\
212 \\
118 \\
47\end{array}$ \\
\hline Mean & $113 \cdot 46$ \\
\hline Range & 104 to 120 \\
\hline Variance & 2.938 \\
\hline
\end{tabular}

Carmichael \& Rice (1920) and others have shown that the gestation period of the pig is slightly longer in the first than in subsequent pregnancies. A similar trend was seen in the present study. The average of 693 first pregnancies was 113.65 days, 0.36 of a day longer than the average of 757 subsequent preg-

TABLE 2

RELATIONSHIP BETWEEN DURATION OF FIRST GESTATION PERIOD AND THE PROBABILITY OF FARROWING A SECOND LITTER

\begin{tabular}{c|c|c}
\hline No. litters & $\begin{array}{c}\text { Average No. } \\
\text { days in first } \\
\text { gestation }\end{array}$ & $\begin{array}{c}\text { Probability of } \\
\text { farrowing } a \\
\text { second litter }\end{array}$ \\
\hline 66 & $110 \cdot 3$ & $0 \cdot 86$ \\
78 & $112 \cdot 0$ & $0 \cdot 79$ \\
145 & 113.0 & 0.81 \\
127 & 114.0 & $0 \cdot 77$ \\
106 & 115.0 & 0.72 \\
85 & 116.4 & 0.70 \\
\hline
\end{tabular}

nancies. In this herd, most females were given an opportunity to conceive and to farrow a second time. Some females, chosen at random after their first litter, were used in special studies and none of the records are included here. Death, infertility and major disabilities caused $23 \%$ of the sows which farrowed once, 
to fail to farrow a second time. The relationship between the average length of the first gestation and the probability of producing a second litter is given in Table 2 for all females which had an opportunity to farrow twice. The results show that each additional day in the first gestation reduced the probability of a second litter by about 0.03 .

The breed differences noted here and in other studies demonstrate a genetic influence on the duration of gestation. Genetic variation within breeds was also evident. The sire of the litter had a significant influence on the length of gestation, and the heritability of differences among sows within a breed was about $30 \%$. More detailed analysis of the genetic variation will be presented elsewhere.

Journal Paper No. J-4761 of the Iowa Agricultural and Home Economics Experiment Station, Ames, Iowa. Project No. 1424. This work has received assistance from Contract AT(11-1)-707 from the U.S. Atomic Energy Commission.

\section{REFERENCES}

Biggers, J. D., Curnow, R. N., Finn, C. A. \& McLaren, A. (1963) Regulation of the gestation period in mice. F. Reprod. Fertil. 6, 125.

CARmichaed, W. J. \& RicE, J. B. (1920) Variation in farrow; with special reference to birth weight of pigs. Illinois agric. Exp. Sta. Bull. No. 226.

Willham, R. L. \& Cox, D. F. (1962) Effect of paternal irradiation on 154 day weight in swine. Genetics, 4, 1639. 